\title{
Ethnicity, Gender and Entrepreneurial Tendencies: The Singapore Perspective
}

\author{
Ramin CoOper Maysami And Christopher Ziemnowicz
}

\begin{abstract}
Creativity and risk-taking, widely accepted prerequisites for successful entrepreneurial behaviour, were absent for a long time from Singaporean culture, where people were accustomed to well paying and readily available jobs in the public sector. As a result of the economic slowdown of the late 1990s, promoting entrepreneurial activities became a priority of the Singapore government. This study analyzes the entrepreneurial characteristics of Singapore's multi-racial and multi-cultural society, and attempts to find if there are any reasons as to why some people are more readily willing to engage in entrepreneurial behaviour, based on factors such as race, gender, and culture.
\end{abstract}

Keywords: Entrepreneurship, culture, innovation, risk propensity, Singapore

\section{Introduction}

A new enterprising breed which dares to dream big and risk failure is what the country needs. Lee Kuan Yew ${ }^{1}$

Since gaining independence in 1965, labour-starved Singapore has increasingly moved towards adapting capital-intensive production systems to replace the previous labour-dependent methods. Moreover, the goal of many Singaporeans at that time was to obtain the well-paying and readily available jobs that were available in the public sector. The economic slowdown of the late 1990s resulted in greater attention being paid to entrepreneurial characteristics such as creativity, innovation, and risk-taking.

The country now aims to move another step forward, and categorize itself as a knowledge-intensive society. In the words of Singapore Minister Mentor (MM) Lee Kwan Yew, 'In this new phase, it is people with the imagination, drive, willingness to think big and take risks to bring their ideas into the commercial marketplace, who will make 
the economy grow, make themselves rich, and provide jobs for our people ${ }^{2}$.

Ray (1990) asserts that human resources management and local enterprise development are effective paths to economic growth in countries such as Singapore that lack natural resources. Singapore's Minister of Trade and Industry, Lim Swee Say, agrees: 'we need to turn creative ideas into the raw materials in our economy, and innovation into the driving force of economic growth ${ }^{13}$. Likewise, Senior Minister Goh Chok Tong has urged Singaporeans to become more entrepreneurial and less averse to taking risks if they want to succeed in the global economy ${ }^{4}$, as risk taking, innovation, and entrepreneurship have been identified as important factors contributing to success in today's highly competitive economy.

Although these factors are not instant remedies for all economic problems within a nation, numerous studies have identified that innovation and entrepreneurship provide benefits for individuals and companies, as well as improving a nation's economy. For the purposes of this discussion, innovation can be defined as the successful introduction and adaptation of any new structure, concept, product, approach, or process within an organization's operation. However, newness is determined by something being new to the organization, and not necessarily something completely original to the world at large. Innovation is thus an economic and social concept, rather than purely a technical term. An entrepreneur, who is a profit seeking risk taker, commonly carries out innovations and introduces creativity. Entrepreneurs decide which projects to undertake and how they should be undertaken. The success of an entrepreneur can also be measured by the increase in value of available resources. To be successful, an entrepreneur must convert and rearrange resources in a manner that will increase their value (Duymedjian and Ansart 2007), thus expanding the production possibilities of the existing resources. Firms pursue new ideas, challenge different approaches and exploit change. They provide energy and flexibility to risk everything, even failure, to meet challenges.

Taking the view that entrepreneurship is 'an engine for economic growth', the Singapore Ministry of Education (MOE) has been contemplating various alternatives to stimulate creative thinking among students at an early stage in their education. This strategy is based around Singapore's multi-racial and multi-cultural citizens, and the belief that factors that contribute to the entrepreneurial spirit are related to race and culture. In addition, the government is helping to promote an entrepreneurial spirit by developing a conductive environment for 
entrepreneurial activities, through granting various incentives and assistance to business start-ups.

Examples of these include the Business Angel Fund that was launched by the National Science and Technology Board, to encourage co-investment in selective technology start-up companies. Similarly, the Local Enterprise Financing Scheme (LEFS) is designed to encourage and assist local enterprises to upgrade, strengthen, and expand their operations. This is administered by the Productivity and Standards Board and offered through 28 participating financial institutions. The government also revised the Bankruptcy Act to encourage a higher degree of entrepreneurship and risk-taking.

Various demographic factors have been shown to have an influence on the entrepreneurial inclination of the individual. A few of factors in the literature include age (Blanchflower, Oswald, and Stutzer 2001), gender (Cromie 1987; Fagenson \& Coleman 1987; Sing, Reynolds \& Muhammad 2001), perceptual experience (Arenius and Minniti 2005), and the level of education (Cooper \& Cascon 1992). Cultural-based beliefs and behaviour are other major determining variables.

Gasse (1982) suggested that some societies appear to breed entrepreneurs more readily than others, while Redding (1986) noted that certain ethnic groups appear to exhibit more entrepreneurial spirit. Often, the lack of entrepreneurial ventures may be the result of cultural barriers rather than the lack of economic opportunities. In the United States, for example, where entrepreneurs receive high recognition, entrepreneurship can flourish, and the entrepreneur may even be seen as a folk hero in popular culture. There it is better to have tried and failed in business than not to have tried at all.

In addition to these findings, there is extensive research into the relationship of entrepreneurship to factors such as race and ethnicity, for example, in the work of Rosenstien and Light (1995). Research into cultures and the degree of emphasis on goal attainment and success, show numerous differences among nations. Although the relationship between nations and culture does not have a direct relationship, generalizations help illustrate important differences. For example, Timmons et al (1985) postulated that certain Chinese cultural values are in direct conflict with commonly agreed upon entrepreneurial characteristics. Within the dynamic business environment, culture is the single variable that affects every facet of any enterprise. Moreover, issues of culture, communication, and other related variables arise from the fact that individuals in any business firm are socialized in three dimensions 
- into their culture, into their business, and into their corporate culture (Terpstra 1991). In addition to these cultural factors, there has been a move to modernise the traditions and laws regarding women's status and opportunities in Singapore.

As stated, Singapore is a multi-racial, multi-cultural society composed of Chinese, Malay, and Indians as well as mixed-raced 'Eurasians'. Each ethnic group has retained its own culture, customs, and traditions, and have learned to live harmoniously with each other. This unique blend of cultures in Singapore has motivated this research, the purpose of which is to ascertain the relationship between culture, gender, and entrepreneurial spirit among Singaporeans.

In summary, the primary objective of the study is to find whether distinct cultural values of the Singaporean Chinese, Malays, and Indians affect their respective entrepreneurial spirit. It is hoped that this will provide a starting point for formulating different strategies to promote the entrepreneurial spirit among various racial groups.

The remainder of this study is organized as follows: the next section briefly defines entrepreneurs and entrepreneurial characteristics. The influence of culture on entrepreneurial activities is also discussed. Next, the result of a survey to assess the impact of ethnic Singaporean culture on entrepreneurial spirit is given. A discussion of the results follows, based on the observed cultural factors. Finally, in light of the findings, recommendations are given.

\section{Literature Review}

Entrepreneurship can be defined as an ability within the individual 'to locate new ideas and put them into effect'. As Baumol (1968) asserted over three decades ago, the entrepreneur 'must lead, perhaps even inspire to effectively complete this function'. Prior to this, Schumpeter (1954: pp. 87-88) suggested 'economic development would emerge when 'new combinations' appeared discontinuously'. New combinations include the introduction of a new good or a new quality of a good, the introduction of a new method of production, the opening of a new market, the conquest of a new source of supply of raw materials and components, and the reorganization of any industries. The execution of the new combination he called enterprise, and the individuals who executed them, he called entrepreneurs.

Entrepreneurship has since been defined in various ways. For example, as a creative activity whereby the entrepreneur introduces 
something new into the economy (Setty 1980) or an act of innovation that involves endowing existing resources with no wealth-producing capacity (Drucker 1985), and a process by which individuals pursue opportunities without regard to the resources they currently control (Stevenson et al. 1989). The entrepreneur is viewed as an innovator who is the ultimate value-adding component in the chain of innovation from 'idea' to a commercially successful business. He perceives profit opportunities and initiates action to fill unfulfilled needs or improved inefficiencies (Kirzner 1982). In short, entrepreneurs are what they do, not who they are.

The hypothesis that cultural factors may enhance or inhibit the desire to express enterprise in a business context is well documented (Weiss 1988; Maysami and Goby 1998a). According to Thomas and Mueller (2000) culture, representing the shared values and beliefs of a society, is an important contextual factor affecting the number of potential entrepreneurs in a given community, region, or country. They suggest that identifying the nature of the relationship between culture and entrepreneurship can provide governments with information necessary for targeted programs intended to motivate new venture creation, thereby increasing employment and adding to economic vitality and flexibility.

Moreover, the emphasis placed on entrepreneurship is not the same across different cultures. Shapero (1984) concluded that culture is an explanatory variable for entrepreneurial activity, or the lack of it. In the opinion of Long (1996), a culture that rewards and values ethical enterprising behaviour, and has markets that are open to entrepreneurial participants wishing to pursue potential economic and physical gains, will indeed stimulate entrepreneurial activity. By contrast, Becker (1956) has noted that some societies consider business as an unholy activity, and so entrepreneurial behaviour is also frowned upon.

The success of Chinese business people, for example, has been linked to their personal characteristic (Kirby and Fan 1995) and management style ( $\mathrm{Ng}$ and $\mathrm{Ng}$ 1994). According to Maysami et.al (1998b), the basic values underlying Chinese business ownership are networking and diligence. They also noted that personal relationships underlie the dynamics of Chinese business dealings. In addition, Wu (1983) has identified some Chinese cultural values that that help to further explain the success of Chinese business owners. These include practices such as a high propensity to save, tendency to reinvest business earnings, and a universally strong desire to secure a better education for their children, who would then be expected to carry on their business, 
It is important to distinguish small business projects and entrepreneurial ventures. A small business may be any enterprise that is (1) independently owned and operated, (2) not dominant in its field, and (3) does not engage in any marketing or innovative practices. On the other hand, an entrepreneurial venture is often characterized by (1) innovative strategic practices, and (2) principal goals of profitability and growth. Entrepreneurs also embrace innovation and engage in strategic management practices. Such behaviour is not always typical for small business owners or managers.

Following this proposition, small business owners or managers should therefore display certain characteristics if they are to be categorized as entrepreneurs: (1) they must be innovative, (2) they should always inject new ideas and propose new ways of doing things, (3) they explore new markets, and (4) they initiate new projects. Chell et. al. (1991) listed the defining characteristics of entrepreneurs to include opportunistic, innovative, creative, imaginative, proactive, agents of change and ideas-people. Gibb (1985) has argued that three of the most frequently mentioned entrepreneurial attributes, flexibility, creativity, and innovation, are missing from the list of Chinese cultural values. Hornaday (1982) added two other attributes, positive response to change and profit-orientation, to this list.

Meanwhile, the entrepreneurial environment in the Malay community is apparently even less vibrant compared to the Chinese. In the opinion of Choy and Ismail (1991), the predominant reason, is the lack of a cultural tradition that supports such activities. They contend that an individual's locus of control in the Malay community is external and wealth is transient, while Hamzah-Sendut et al. (1990) agree that Malays tend to dislike materialism and seek the idea of social harmony and mutual co-operation. However, research on the relationship between Indian culture and entrepreneurship is more limited.

\section{Methodology and Data}

To further examine the relationship between Singaporean Malay, Chinese, and Indian cultures and entrepreneurial spirit, a comprehensive survey was carried out.

As a wide range of characteristics are attributed to entrepreneurs (Capati, 1986), in designing the survey, this study has taken into account the influential works of Sexton and Bowman (1985), Brockhaus and Horwitz (1986), and Begley and Boyd (1987). Six characteristics are 
found to be more predominant in the psychology of entrepreneurs and were thus selected for the measurement of entrepreneurial spirit: (1) creativity, (2) locus of control, (3) risk-taking, (4) need for achievement, (5) determination, and (6) self-efficacy.

Creativity is regarded as being essential to a successful entrepreneur. Entrepreneurs are frequently described as being innovators, for 'without innovations there is no entrepreneur' (McGraw 1991). From this, the following hypothesis is formed and tested:

$\mathrm{H}_{\mathrm{o}}$ : There is no significant difference in the level of creativity among the Chinese, Malays, and Indians in Singapore

An internal locus of control is another commonly posited psychological character of entrepreneurs (Perry 1990), for, 'entrepreneurs have confidence in their own ability to achieve their goals through their own efforts, as opposed to luck, fate or external circumstances' (Rotter 1966). With confidence, comes the willingness to take risk. Cunningham and Lischeron (1991), suggested that risk-taking is one of the major entrepreneurial characteristics. Mill (1984) has similarly suggested risk-taking as the key factor in distinguishing entrepreneurs from managers.

Meanwhile, according to McClelland (1961), entrepreneurs prefer to set their own goals and are driven by their own need for achievement. According to Sjaver and Scott (1991), this need for achievement is a strong driving force behind human action influencing entrepreneurial behaviour, and is the driver that pushes the individual to greater efforts (Capati 1986). A further important characteristic is determination, one that would be expected in an individual with high achievement needs. According to Kao (1993) an entrepreneurial sprit is an aggressive and determined business attitude.

Cunningham and Lischeron (1991) found entrepreneurs to have a higher degree of self-efficacy relative to non-entrepreneurs. Furthermore, research findings by Krueger et al. (1999) demonstrated a positive relationship between perceived self-efficacy and entrepreneurial intention. Individuals who are have high entrepreneurial self-efficacy have higher levels of entrepreneurial intention.

Five other hypotheses are thus formed and tested:

$\mathrm{H}_{\mathrm{o}}$ : There is no significant difference in the level of [(2) locus of control, (3) risk-taking, (4), need for achievement (5), determination, and (6) self-efficacy] among the Chinese, Malays, and Indians in Singapore. 


\section{Questionnaire Design}

The questionnaire comprised two sections. The first identified the demographic characteristics of the sample, and the second part comprised thirty statements aiming to determine the respondents' level of entrepreneurial spirit through an assessment of the above-mentioned six characteristics. Each of the characteristics was appraised using five statements adapted from the studies by Levenson (1974), Robinson et al. (1990), and the Entrepreneurial Self-Assessment Scale in the 'Entrepreneur's Handbook' (1981).

The questionnaire used a 5-point Likert Scale to indicate the degree of the respondent's agreement or disagreement with each statement (Elmore and Beggs, 1975, have shown that a 7- or 9-point scale does not improve the reliability of the ratings). To minimize response-set bias and the halo effect, certain statements were reverse-scored and mixed with others. Before the questionnaire was finally distributed, a pilot test was conducted on a small sample of fifty respondents. Minor amendments were then made to improve its format and readability.

\section{Data Collection}

The sample respondents consisted of residents from Housing Development Board (HDB) estates. These are best described as self-contained towns that constitute the residences of almost 90 percent of Singaporeans (Singapore Population Census 2000). The ones chosen for the research were in Yishun, Tampines, Jurong and Redhill, representing the northern, eastern, western and central districts of the country. To prevent bias in selecting the best sample, five HDB blocks in each housing estate were selected randomly from the 2002 Singapore street directory. Beginning with the first household on each floor of the block, every subsequent fourth household was surveyed.

A total of 353 responses were collected. Twenty were rejected due to incomplete answers or because they were of races other than Chinese, Malay, or Indian. The remaining 333 responses, of which 229 were Chinese, 56 were Malays, and 48 were Indians, were used in the analysis. 
Table 1 depicts the descriptive characteristics of the sample in terms of gender, age, marital status, and education level.

TABLE 1: Descriptive statistics.

\begin{tabular}{|l|c|c|c|}
\hline \multirow{2}{*}{ GENDER } & Male & 123 & $36.9 \%$ \\
\cline { 2 - 4 } & Female & 210 & $63.1 \%$ \\
\hline \multirow{3}{*}{ RACE } & Chinese & 229 & $68.8 \%$ \\
\cline { 2 - 4 } & Malays & 56 & $16.8 \%$ \\
\cline { 2 - 4 } & Indians & 48 & $14.4 \%$ \\
\hline \multirow{3}{*}{$\begin{array}{l}\text { MGE } \\
\text { STARITAL }\end{array}$} & Below 21 & 30 & $9.0 \%$ \\
\cline { 2 - 4 } & $21-30$ & 202 & $60.7 \%$ \\
\cline { 2 - 4 } & $31-60$ & 101 & $30.3 \%$ \\
\cline { 2 - 4 } & Single & 219 & $65.8 \%$ \\
\cline { 2 - 4 } & Married & 109 & $32.7 \%$ \\
\cline { 2 - 4 } EDUCATION & Others & 5 & $1.5 \%$ \\
\cline { 2 - 4 } & Tertiary & 131 & $39.1 \%$ \\
\cline { 2 - 4 } & Non-tertiary & 202 & $60.9 \%$ \\
\hline
\end{tabular}

\section{Statistical Methods}

A one-way analysis of variance (ANOVA) test was performed to investigate significant differences in the six entrepreneurial characteristics among the three racial groups. Additionally, a one-sample t-test was conducted on each of the entrepreneurial characteristics where significant differences among the three ethnic groups were deduced. Here, the sample mean score for each characteristic was used as the test value. In essence, the entrepreneurial characteristics of each racial group were compared with the average respondent. A racial group was considered high on a particular characteristic when their mean score was higher than the test value.

\section{Results}

The results of the one-way ANOVA test, as depicted in Table 2, showed significant differences among the three racial groups in creativity, need for achievement and locus of control. However, no significant differences were shown among the three racial groups as far as determination, risk taking and self-efficacy are concerned. 
TABLE 2: Entrepreneurial characteristics - central tendencies.

\begin{tabular}{|l|c|c|}
\hline $\begin{array}{l}\text { ENTREPRENEURIAL } \\
\text { CHARACTERISTICS }\end{array}$ & MEAN & STANDARD DEVIATION \\
\hline Creativity & 16.81 & 1.90 \\
\hline Determination & 18.39 & 2.68 \\
\hline Risk-taking & 16.05 & 2.65 \\
\hline Need for Achievement & 18.66 & 2.48 \\
\hline Self-efficacy & 15.67 & 2.53 \\
\hline Locus of Control & 16.54 & 2.77 \\
\hline
\end{tabular}

TABLE 3: Summary of Anova results

\begin{tabular}{|l|c|c|c|}
\hline $\begin{array}{l}\text { HYPOTHESIS } \\
\text { On differences in: }\end{array}$ & Test Value. & Results & $\begin{array}{c}\text { Significant Dif- } \\
\text { ferences among } \\
\text { ethnic groups? }\end{array}$ \\
\hline Creativity & $0.010^{*}$ & Reject $\mathrm{H}_{0}$ & Yes \\
\hline Determination & $0.158^{*}$ & Accept $\mathrm{H}_{0}$ & No \\
\hline Risk-taking & $0.243^{*}$ & Accept $\mathrm{H}_{0}$ & No \\
\hline Need for Achievement & $0.033^{*}$ & Reject $\mathrm{H}_{0}$ & Yes \\
\hline Self-efficacy & $0.180^{*}$ & Accept $\mathrm{H}_{0}$ & $\begin{array}{c}\text { No } \\
\text { Leject } \mathrm{H}_{0}\end{array}$ \\
Locus of Control & $0.040^{*}$ & Yes \\
\hline
\end{tabular}

* Significance level of 0.05

TABLE 4: Summary of one-sample T-test results.

\begin{tabular}{|c|c|c|c|c|}
\hline $\begin{array}{l}\text { HYPO- } \\
\text { THESIS }\end{array}$ & Test Value* & Race & Mean & Conclusions \\
\hline \multirow{3}{*}{ Creativity } & \multirow{3}{*}{16.81} & Indian & 17.46 & High \\
\hline & & Malay & 17.07 & High \\
\hline & & Chinese & 16.62 & Low \\
\hline \multirow{3}{*}{$\begin{array}{l}\text { Need for } \\
\text { Achievement }\end{array}$} & \multirow{3}{*}{18.66} & Indian & 19.52 & High \\
\hline & & Malay & 18.57 & Low \\
\hline & & Chinese & 18.50 & Low \\
\hline \multirow{3}{*}{$\begin{array}{l}\text { Locus of } \\
\text { Control }\end{array}$} & \multirow{3}{*}{16.54} & Indian & 17.25 & High \\
\hline & & Malay & 16.96 & High \\
\hline & & Chinese & 16.28 & Low \\
\hline
\end{tabular}

* Significance level of 0.05

The results obtained from the one-sample t-test are presented in Tables 3 and 4 . The test was performed on characteristics of creativity, need for achievement, and locus of control that differed significantly among the three racial groups. The results showed that the mean scores for the Indians in each of the three categories were the highest. For the Malays, 
the mean scores for creativity and locus of control were slightly above that of an average respondent. However, their mean score for need of achievement was below average. The mean scores on creativity, need for achievement, and locus of control for the Chinese sample were the lowest.

In brief and based on the findings from this questionnaire, this study concludes that Singaporeans of Indian origin are the most entrepreneurial among the country's three racial groups, and the Chinese are the least.

\section{Discussion}

These findings lead us to ask, why do the different groups show varying degrees of creativity, locus of control, and need for achievement, while at the same time there are no significant differences among them in terms of risk-taking, determination, and self-efficacy? This report postulates that specific cultural values and beliefs inherent among each ethnic group are primary contributors to these findings. The next section explores possible links between culture values and the presence, or lack of, entrepreneurial characteristics among the three ethnic groups in Singapore.

\section{The Indians}

Religion plays an important role in the life of every Indian. Hinduism is forms the ethos of the majority of Indians, including those who have migrated to Singapore (Srinivasan 1990). As such, religion paves the way to the understanding of Indian culture.

The doctrines of Karma and transmigration have greatly shaped Indian culture, and even today the influence is alive and active, according to Sumathi (1994). Indians believe that the success of a man is under his own control and that he will reap what he sows. As Bose (1990) puts it, 'man is the sole and absolute master of his fate'. This internal locus of control is further supported by the belief in transmigration, in which a man's rebirth is determined by the cumulative good or bad actions of his previous lives (Srinivasan 1990). Hinduism believes in the eternity of soul and its reincarnations that eventually lead to final liberation or moksha (Kishore 1996). Hence, Indians feel that they and their actions alone are accountable for their eternal liberation.

In addition to having a high internal locus of control, Indians possess a high need for achievement. Hinduism advocates the quest for right- 
eous living, love, and happiness, and wealth and prosperity (Srinivasan 1990). As asserted by Kishore (1996) these attitudes encourage people to continuously seek excellence in what they do, since the path to salvation lies in one's good actions (karmas). With their thirst for knowledge, Indians are universal in their outlook, according to Sumathi (1994), and are receptive of new ideas and willing to learn from other people.

Moreover, the Indians are a family-oriented community (Stern 1993). According to Sumathi (1994), living in and being raised among large families has endowed Indians with a great sense of security and group identity, but relatively little individuality (individualism and the neglect of the wants of others in the community are indeed considered selfish). Hence, Wolpert (1991) argues that conformity to the family and authority becomes the first law of Indian life and a major limiting factor to creative growth, radical change, or independent initiative.

This statement apparently contradicts the finding of this study, in which Indians have been ascertained to possess high creativity. The discrepancy may be explained by the growth of individualism as a result of urbanization, changes in employment patterns, and economic development in Singapore (Sumathi 1994). Moreover, Hinduism accepts the validity of many paths leading to the same goal (Hofer 1997). This suggests that creativity and individualism may no longer be constrained, but rather, a natural characteristic of the Indians.

\section{The Malays}

Bedlington (1971) argues that the Malay idea of rezeki or belief in the predetermination of man's economic destiny, results in fatalism and a 'lack of will to go on striving'. In the same vein, Noordin (1996) states that the Malay belief in fate - that Allah has a predetermined plan for them - may sometimes lead to the unquestioning acceptance of the order of things. Everything that happens, whether good or bad, is attributed to God's will. Rajaratnam (1991) reiterates the feudalistic consciousness (fatalism) of the Malays. From these comments, one may be lead to believe that Malays possess a high external locus of control. Findings from this survey, however, were that the Malays displayed higher than average internal locus of control.

The findings from the survey are indeed supported by a group of educated Malay elite, comprised of members of the Muslim society at the National University of Singapore and leaders of various other Malay and Muslim associations. They have argued that Malay values, and in particular, incorrect interpretations of Islam, are the causes of their 
lag in economic prosperity. The belief in a pre-destined future without the need to make an effort (as a result of a passive attitude towards religion) may have lead to fatalism, an over concern with rituals and satisfaction with short-term results. Such beliefs have been described as negative, non-progressive, mistaken. Moreover, it has also been stated that non-Islamic views have crept into Malay's interpretation of Islam (NUS Muslim Society and NUS Malay Society 1982), which has had a negative effect.

Rahim (1979) asserts that Islam stresses work and effort, forbids laziness, involves long-term planning, problem solving as well as forbidding waste, arrogance, complacency, and despair. These give support for the notion of internal locus of control that may be inherent in the Singaporean Malay culture.

Malay culture may also have a role in shaping their attitude towards the accumulation of wealth through entrepreneurial activities. In the ethos of Malay society, the unrelenting pursuit of an objective, like the accumulation of wealth, is not held in esteem and is thus given low status. In fact, it is condemned as inconsistent with gracious living on which they place much importance (Goh 1977). According to Noordin (1996), respect and status in the Malay community is earned not through material possession but through friendliness, neighbourliness and willingness to lend a hand in times of trouble. Furthermore, high priority is placed on personal happiness, which does not necessarily come from wealth.

In the Malay view, precise and explicit calculation, or the blatant pursuit of maximum profit with no consideration for the other party, negates social relationships which are developed between individuals on the basis of a mutual willingness to 'give' (Li 1989). As a result of their reluctance to commercialize family relationships and the tendency to personalize commercial relationships, the possibility and acceptability of personal advancement through entrepreneurship may be inhibited.

Mendaki (1993) proposed that the nature of the 'Singaporean' way of life demands an almost obsessive interest in economic development, whereas Islam demands reasonable limits on materialism. This conflict may have lead the Malays to be less influenced by pressures to assimilate into the urban, industrialized, time-conscious and competitive world of many Singaporeans. This, in turn, proposes support for the ideology that Malay culture does not advocate a strong need for achievement (especially in terms of monetary pursuit), a fact that is reflected in the findings of this study. 


\section{The Chinese}

The most influential beliefs that form the foundation of Chinese cultural traditions, and still provide the basis for the norms of Chinese interpersonal behaviour, is Confucianism (Pye 1972). It is often pointed out that the Chinese in Singapore have always been Confucian in their thinking and behaviour, even if only subconsciously, and that Singapore Chinese society is Confucian in value orientation and organizational structure (Kuo 1986).

Indeed, Confucianism was revitalized in Singapore in the 1970s with the 'Speak Mandarin' drive. This campaign may have raised the level of consciousness among the Chinese population about what it means to be Chinese. Lian (1999) has stated that this, along with the promotion of Confucian ethics in the 1980s, has resulted in Singapore being an active player in the so-called re-invention of 'Chineseness'.

Confucianism as the behavioural or moral doctrine based on the teaching of Confucius, governs human relationships, social structures, virtuous behaviour and work ethics (Kirby \& Fan 1995). The ideal man envisaged by Confucius is not a successful entrepreneur, but a scholar bureaucrat. The key value is harmony and order, and taking initiative and innovation may be viewed as a threat to social harmony. This may explain why key entrepreneurial values such as creativity, initiative, and innovation are missing from the vocabulary of Chinese values.

Entrepreneurs generally have an internal locus of control while ethnographic evidence has shown that fatalism with regard to personal economic destiny exists in the Singapore Chinese culture (Wee 1976; Leong 1978; Lai 1973). This supports the result of this study, which shows that Singaporean Chinese have an external locus of control.

The need to achieve has always been inherent among the Chinese in Singapore, and has become more pronounced in post independence times (Cheng 1985). The Chinese are easily unsettled by other people's judgements and have thus developed a defensive nature. Even confident people are susceptible to being controlled by fear of shame. This fear of shame or "saving face" as commonly phrased in Singapore, spurs the Chinese to hunger for achievement and to seek success (Tamney 1996).

On the other hand, the Singapore Population Census of 2000, revealed that Chinese, with an average household income of $\$ 3,848$, are the most affluent among the three races. With 58 percent of the Singaporean Chinese attaining Secondary school or above qualifications, they also have the highest education profile. As a result of their economic and academic 
success, the Chinese in Singapore may have been entrenched in their own comfort zone, thus reflecting their low need for achievement.

\section{Similarities among the three Racial Groups}

The findings of this study show no significant difference among the three groups in terms of risk-taking, determination and self-efficacy. We postulate that ethnic and cultural factors are not strong advocates for these entrepreneurial characteristics among Singaporeans. Instead, there may be plausible reasons for similarities between the Singaporean Chinese, Malay, and Indians as far as risk-taking, determination and self-efficacy are concerned.

First and foremost, the Singapore government has channelled vast efforts into the promotion of a Singaporean national identity, and has been, by most accounts, successful (Tong and Pakir 1996). The development of this overarching national identity seems to have resulted in different communities being encouraged to accept the same set of parameters for dealing with certain important issues in the society.

In addition, the majority of Singaporeans, regardless of ethnicity, are exposed to the English-medium, unified educational system, where schools use a common syllabus and students take common examinations. This may also have imparted a common set of values English was adopted as the main medium of education for pragmatic reasons according to Tong and Pakir (1996). The only choice available to a small, yet multi-cultural and potentially multi-lingual country such as Singapore, to become a part of the international grid of business and finance, was to adopt the English language. Tham (1996) supports this view by asserting that the adoption of English as the official language has been instrumental in realizing Singapore's development objectives.

The promotion and usage of English as an official language in the workplace has provided a common platform where different racial groups can communicate effectively with one another. This has reduced communication breakdown, and at the same time, has increased the opportunities for different races to better understand one another's culture, and perhaps develop a unified value system.

Finally, increased and continuous interaction among the three racial groups is brought about by the gradual 'levelling' of lifestyles, housing policies, and occupations. Integrated schools and ethnic mixing in the new housing estates have indeed promoted a higher degree of social interaction, and may further explain the blurring of cultural boundaries in Singapore. From this, it is necessary to ask what are the possible causes 
of the less than desired level of risk taking, self-efficacy and determination among Singaporeans, regardless of their race?

In the drive for growth and economic success, the Singapore system has become the epitome of meritocracy, claim Wong et al., (1993). The local system rewards those who follow a tried and tested path to success. Perceived to be a disgrace, failure in entrepreneurial efforts may bring shame to the individual and family, and should be avoided at all costs. The stigma of failure may have thus resulted in a society that is highly risk adverse. SM Lee reiterates this point: 'we have got a society which is risk adverse because we have been too successful and we have too few failures ${ }^{15}$.

In addition, the proportion of those in managerial and professional positions has jumped from 10 percent to 24.4 percent of the labour force in the last ten years. Good salaries, attractive packages and career advancements associated with positions in large reputable corporations, constitute a higher opportunity cost in risk taking.

The competitive school and work environment may have also contributed to low self-esteem among Singaporeans. A 1992 national survey, for example, revealed that more than half of the teenagers surveyed had low self-esteem attributed to assessment of personal worth based on academic accomplishments (Gasmier 1992). Career advancements and monetary achievements are the major concerns of the adult Singaporeans. As suggested by Yeo (1985), high flyers are singled out for mention, and achievement is the hallmark of a successful life. The continuous pursuit of excellence, characteristic of Singapore society, may have adversely affected the self-efficacy of its people.

The economic policies of the Singapore government have been hugely successful in increasing growth and affluence. According to the Singapore Population Census 2000, the economy expanded over the previous decade at an average GDP growth of 7.7 percent per year. The average monthly income doubled to \$2,200 between the years 1990 and 2000 . Home ownership rate increased from 87.5 percent to 92.3 percent in the same period while car ownership by household jumped from 28 percent to 31.7 percent.

These national achievements may have lead Singaporeans, especially the younger generation, to be complacent, heightening their reluctance to leave their comfort zone. This, evidently, has resulted in their lack of diligence and determination. In addition, while the abundance of employment opportunities provides a safety net for working adult, it may have held back their level of determination, as they lack the motivation 
to persevere in face of obstacles faced in innovative entrepreneurial endeavours.

\section{The role of women in business ventures}

Deng, Hassan and Jivan's (1995) Asian study note that the majority of women business owners in the region are in their 30s and early 40s. Similarly, Singaporean female entrepreneurs have an average age of 41 and are mostly married with two children (Teo 1996). Female Singaporean business owners have at least 10 years schooling, while 35 percent held first or postgraduate degrees, 15 percent had professional or polytechnic qualifications, and 50 percent had completed secondary-level education.

Collerette and Aubury (1991) showed that prior to setting up their ventures, the majority of female business owners had previous work experience. Although female-owned businesses are well diversified and range from service to manufacturing, the majority of female business owners in Singapore seem to be in the service and retail industries. This may be the result of the high start up costs involved in manufacturing and construction sectors, as well as prospective female business owners' lack of prior experience and technological skills in these areas. Consequently, female-owned businesses in Singapore usually start as small service and retail ventures with few employees, and grew over the years to become progressively more established. The majority of Singapore female-owned businesses have been in operation for an average of nine years.

Business ownership structure seems to affect the way female business owners manage their venture as well. When run by women, businesses registered as private limited companies and sole proprietorships were more successful than partnerships (Rashid 1996). Perhaps it is then not surprising to find that 64 percent of female-owned businesses in Singapore are private limited companies, 21 percent are partnerships, 14 percent are sole proprietorships, and only 1 percent is publicly owned.

\section{Motivations, Problems, and Success Factors}

In the opinion of Hisrich and Brush (1986), in general, women are primarily motivated by the need for independence as opposed to men who are motivated by material rewards. Lee-Gosselin and Grise (1990) note that the idea to start a business originates almost exclusively from 
women business owners to 'fulfill an old dream, a desire for recognition by others, the desire to put one's knowledge and skills to use, a continuity to training or work experience, or the desire to be independent and have control over one's life'.

The five major factors which best motivate Singaporean female business owners in particular are cited by Teo (1996). These are the identification of business opportunities, the desire to put their knowledge and skills into use, the need for freedom and flexibility, the desire to achieve personal growth and recognition, and the need to make more money for financial independence. It was, moreover, the prospective female owners' own personal decision to start a business in fulfilling their sense of self-worth, and not family and friends' influences, that inspired them. As motivators in arriving at their decision, Singaporean women mentioned loss of job or inability to find a suitable job, encouragement by the government, taking over the family business, and finding the previous job too demanding and stressful.

This is maybe an Asian trait: 66 percent of female entrepreneurs doing business in Asia were motivated primarily by the desire for autonomy, and the freedom and flexibility offered in running one's own business, as observed by Deng Deng, Hassan and Jivan (1995) Among this majority, 22 percent cited that money and profits were additional driving forces in their decision to set up their own businesses while the remaining 34 percent were motivated by personal crises, social considerations and family loyalty.

The most common start-up problems faced by women seem to have been a lack of start-up capital, coupled with a lack of confidence in the abilities of female business owners' by banks, suppliers, and clients alike, as well as family issues. For Singaporean female business owners, the most critical start-up problems are difficulties in finding labour, obtaining finance, competing with others, establishing credibility and coping with high business costs. Other problems encountered at the launch of the business include marketing, pricing, management, social, interpersonal, production, knowledge, and personal issues. After the launch of the business, women owner/managers, needing to compete for limited resources could be at a disadvantage, since they may lack a track record and thus credibility when applying for bank loans or trying to obtain credit from suppliers. This would clearly affect the operational costs of their enterprises.

Factors that Singaporean businesswomen cite as having attributed to their success are product and service qualities (77 percent), per- 
sonal qualities (73 percent), quality of personnel (66 percent), adequate knowledge of products and services (63 percent), and customer loyalty (61 percent). Other factors reported are the availability of professional advice or government assistance (24 percent), technological advantage (16 percent), and availability of financing and capital (16 percent).

They generally started small sized businesses in the service and retail sectors and required limited use of technology and little initial capital. Moreover, Singaporean female business owners seem to have been already familiar with the area of their vocation and thus did not require any professional services. Moreover, they were also capable of striving hard for success with insufficient funds.

Teo (1996) further found certain relationships between success ${ }^{6}$ and various general characteristics of female business owners in Singapore. First, successful businesswomen seem to be more educated, and thus have more up-to-date knowledge of available technologies through university education. They may also be more aware of the operation of the business world and better trained to put their skills and knowledge to good use.

When considering motivation and how they were encouraged to start, all successful Singaporean female business owners stated that it was their own idea to start a business as compared to 69 percent of the less successful owners. This may suggests that women who on their own thought of starting and running a business are more driven to work hard and to make their businesses a success. Additionally, successful women business owners are motivated by the need to provide financial support for the family and the desire to have control over their lives.

Finally, about three-quarters of successful women business owners in Singapore stated that a good networking system was an important success factor, compared to less than half of the less successful ones who thought so. In the US, similarly, both Woodward (1988) and Kotter (1982) had earlier found that successful businesswomen spent more time developing network contacts before starting their business as well as subsequent to the start of operation. It seems vital, then, to build and maintain good relations with both staff and clients in this competitive environment.

Work experience, on the other hand, does not seem to have much impact on the success of the women-owned businesses in Singapore: 30 percent of the successful business owners had no previous work experience compared to only 3 percent of the less successful ones. 


\section{Concluding Comments}

This study shows similarities in the entrepreneurial characteristics of among three groups in Singapore's multi-racial and multi-cultural society. The principal reason for this leveling out has been the government's predetermined development of a national identity. These policies have contributed to Singapore's business success, as well as to changing cultures. Different ethnic communities now accept the same set of values for dealing with attitudes such as risk-taking, determination, and self-efficacy.

Factors such as race, gender, and culture have been made almost made indistinguishable as the majority of Singaporeans are exposed to a standardized, English-based, and unified educational system. Not only has this imparted a common set of values within the required formal academic experience, but also in all other milieu. The selective use and modification of values from a number of cultures has been blended to form an amalgamated Singaporean value system culture. Moreover, the lifestyle and high degree of social interaction among Singaporeans has achieved a blurring of cultural boundaries.

Nevertheless, some aspects of this manufactured culture are generating tension and challenging the potential opportunities gained from entrepreneurship. For example, following the tried and tested is rewarded, while there is a stigma from failure. A characteristic of Singaporeans is to focus on continuous pursuit of excellence, yet this seems to have adversely affected the self-efficacy of its people. These are some of the factors to help explain a society that is highly risk adverse. This places limits in Singapore's effort to shift into an entrepreneurial-driven mode of development.

The cultural effects of moving to an entrepreneurial-based economic development are significant and this study finds shortcomings in changing the strategy. Moreover, the history of successes in Singapore's economic achievements has promoted a complacent society and people reluctant to move out of their comfort zones. For example, attractive career opportunities within large corporations offer greater rewards than entrepreneurial risk taking. Younger Singaporeans exhibit this behavior, which may further limit future innovative entrepreneurial endeavors. However, enterprises established by females may offer a new source of entrepreneurial potential.

Singapore's experience is controversial, with many perceived and real faults, yet it is undeniably unique. Singapore also serves as one of 
the models for policies to build growth opportunities in other nations. However, the significance of the unique cultural and social makeup of Singapore is important because they are not as comparable with economic development focused on entrepreneurship. Singapore has a particular Asian context and it is substantially different from the environment and cultural experience of nations where entrepreneurial-driven growth has been successful. Further research is required to establish the appropriate cultural values and administrative policies to best benefit from the changes occurring in Singapore.

Ramin Cooper Maysami is chaired professor at Department of Economics, Finance, and Decision Sciences, School of Business Administration, University of North Carolina at Pembroke (ramin.maysami@uncp.edu); Christopher Ziemnowicz is chaired professor at Department of Management, Marketing, and International Business, School of Business Administration, University of North Carolina at Pembroke (ziemnow@uncp.edu).

\section{Notes}

1 Singapore Senior Minister, Lee Kuan Yew, The Straits Times, 11 Feb 2000, p. 1.

2 'Wanted: Risk-takers to add zip to economy', The Straits Times, 11 Feb 2000, pp. 1.

3 Mr. Lim Swee Say, Speech at the 26th Annual Report Awards Presentation Dinner, 24 Nov 1999.

4 'Handsome rewards await those who dare to take risks, says PM', The Straits Times, 4 Feb 2000

5 'Moves to promote risk-taking', The Straits Times, 30 June, 2000

6 Success was measured using net profit growth, sales revenue growth, return on investment or market share. 38 percent of those entrepreneurs who used net profit growth as a measure of success considered an achievement of 6 percent - 10 percent growth per annum to be an indication of a successful business.

\section{REFERENCES}

Arenius, P. and M. Minniti 2005. 'Perceptual Variables and Nascent Entrepreneurship'. Small Business Economics 24 (3): 233-247.

Baumol, W. J. 1968). 'Entrepreneurship in Economic Theory'. The American Economic Review 58: 64-71.

Becker, H. 1956. Man in Reciprocity. New York: Frederick Praeger.

Bedlington, S. S. 1971 'Malays of Singapore: Values in Conflict?' Vol. 3: 43-55.

Begley, T. and D. Boyd 1986. 'A Comparison of Entrepreneurs and Managers of Successful Firms'. Journal of Management 13(1): 99-108.

Blanchflower, D.G., A. Oswald, and A. Stutzer 2001. 'Latent entrepreneurship across nations'. European Economic Review 45(4-6) May: 680-691. 
Bose, M.L. 1990. Social and Cultural History of Ancient India. New Delhi: Concept Publishing Company, pp. 84-88.

Brockhaus, R.H. and P.S. Horwitz 1986. 'The Psychology of the Entrepreneur'. In D.L. Sexton and R.W. Smilor (eds). The Art and Science of Entrepreneurship. Cambridge, MA: Ballinger 1986: 25-48.

Capati, A. P. 1985. 'Cross Cultural Characteristics of Entrepreneurs' in El-Namiki, Janssen, and Capati, (eds). Entrepreneurial Development and Small Industry Stimulation in Developing Countries. Netherlands: Research Institute for Management Science.

Chell E., J. Haworth, and S. Brearley 1991. The Entrepreneurial Personality. Concepts, Cases and Categories. London and New York: Routledge.

Cheng, L.K. 1985. Social change and the Chinese in Singapore: a socio-economic geography with special reference to bang structure. Singapore: Singapore University Press, 235p. Revision of author's thesis (Ph.D.), University of London, 1979.

Choy, C. L. and A. J. Ismail 1991. 'Entrepreneurship Development Among Malays in Singapore: A Community Development Approach', in International Perspectives on Entrepreneurship Research--Proceedings of the First Annual Global Conference on Entrepreneurship Research, Birley, S. and McMilan, IC editors, London, UK, 18-20 February 1991.

Collerette, P., and P. G. Aubury 1991. 'Socio-Economic Evolution of Women Business Owners in Quebec'. Journal of Business Ethics (Netherlands) (9/4 and 9/5) 417-422.

Cooper, A. C. and F. J. G. Cascon 1992. 'Entrepreneurs, Processes of Founding, and New-Firm Performance'. In Sexton and Kasarda (eds). The State of Art of Entrepreneurship, Boston, MA 1992: 301-340.

Cromie, S. 1987. 'Motivations of Aspiring Male and Female Entrepreneurs'. Journal of Occupational Behaviour 8: 251-261.

Cunningham, J. B. and J. C. Lischeron 1991. 'Defining Entrepreneurship'. Journal of Small Business Management 21(9): 45-67.

Deng, S., L. Hassan, and S. Jivan 1995. 'Female Entrepreneurs Doing Business in Asia: A Special Investigation'. Journal of Small Business and Enterprise 12: 60-68.

Drucker, P. 1985. Innovation and Entrepreneurship. New York: Harper \& Row.

Duymedjian, R. and S. Ansart 2007. 'From the Creative Destructor to the Entrepreneur - Bricoleur: A Contribution to Schumpeter's Theory of Entrepreneurial Innovation'. In E.G. Carayannis and C. Ziemnowicz (eds). Rediscovering Schumpeter: Creative Destruction Evolving into "Mode 3". New York: Palgrave Macmillan 2007: 143-170.

Elmore, P. E. and D. L. Beggs 1975. 'Salience of Concepts and Commitment to Extreme Judgements in Response Pattern of Teachers'. Education 95(4): 325-334.

Fagenson, E. A. and L. L. Coleman 1987. 'What Makes Entrepreneurs Tick: An Investigation of Entrepreneurs' Values'. In N. Churchill (ed)_Frontiers of Entrepreneurship Research. Wellesley, MA: Babson College.

Gasmier, M. R. 1992. 'Low Self Esteem among Teens'. The Straits Times, Life! Section. Singapore: Singapore Press Holdings, (20 July).

Gasse, Y. 1982. 'Elaborations on the Psychology of the Entrepreneurs'. In C. A. Kent, D. L. Sexton and K. H. Vesper (eds)._Encyclopedia of Entrepreneurship. New Jersey: Prentice Hall.

Gibb, A. A. 1990. 'Entrepreneurship and Intrapreneurship--Exploring the Difference'. In R. Donkel and A. Miettien (eds). New Findings and Perspectives in Entrepreneurship. Gower, England.

Goh, K. S. 1977. The Practices of Economic Growth. Singapore: Federal Publications.

Gwartney, James D. 1987. Economics - Private and Public Choice. New York: Harcourt Brace Jovanovich. 
Ramin Cooper Maysami and Christopher Ziemnowicz

Hamzah-Sendut, T. S. D., J. Madsen and G. Thong 1990. Managing in a Plural Society. Longman, Singapore.

Hisrich, R. D., and C. Brush 1986. 'Characteristics of the Minority Entrepreneur'. Journal of Small Business Management (October) 1-8.

Hofer, H. 1997. Insight Guides: India. Hong Kong: APA Publications (HK) Ltd.

Hornarday, J.A. 1982. 'Who is Entrepreneur?'. In R. Donkels and A. Miettinen (eds). New findings and Perspectives in Entrepreneurship. Gower, England.

Kao, R.W.Y. 1993. 'Entrepreneurship, Past, Present and ?'. Creativity and Innovation Management 3(1).

Kirby, D. A., and Y. Fan 1995. 'Chinese Cultural Values and Entrepreneurship: A Preliminary Consideration'. Journal of Enterprising Culture 3(3): 245-260.

Kirzner, I. 1982. 'Uncertainty, Discovery, and Human Action: A Study of the Entrepreneurial Profile in the Misesian System'. In Israel Kirzner (ed)_Method, Process, and Austrian Economics. Lexington, Mass: D. C. Heath and Company:143-155.

Kishore, B.K. 1996. India: A Guide. New Delhi: Diamond Pocket Books Pvt. Ltd.

Krueger, N. F. 1999. 'The Cognitive Infrastructure of Opportunity Emergence'. Working paper, National Council of Independent Scholars, Bozeman, MT.

Kuo, C.Y. 1986. 'Confucianism and the Family in an Urban-Industrial Society'. In H. S Walter (ed). The Psycho-Cultural Dynamics of the Confucian Family: Past and Present. Seoul: International Cultural Society Korea 1986:.113-135.

Lai, A. 1973. 'School Under-achievers in an Urban Slum in Singapore'. Academic Exercise in Social Work. Singapore: University of Singapore.

Lai, K. S., W. L. Tan, W. H. Tan and S. C. Wong 1995. 'Entrepreneurial Spirit among Tertiary Students in Singapore'. Journal of Enterprising Culture 3(2):.211-227.

Lee-Gosselin, H. and J. Grise 1990. 'Are Women-Owners Challenging Our Definitions of Entrepreneurship? An in-depth Survey'. Journal of Business Ethics (Netherlands) (9/4 and 9/5) 423-433.

Leong, C. C. 1978. Youth in the Army. Singapore: Federal Publications.

Levenson, H. 1974. 'Activism and Powerful Others: Distinctions within the Concept of Internal-External Control'. Journal of Personality Assessment 38(4): 377-383.

Li, T. 1989. Malays in Singapore: Culture, Economy and Ideology. Singapore: Oxford University Press.

Lian, K. F. 1999. 'The Nation-State and the Sociology in Singapore'. Reading CultureTextual Practice in Singapore. Singapore: Time Academic Press.

Long, W.A. 1996. 'Why Entrepreneurship?'. Entrepreneurs, Entrepreneurship \& Enterprising Culture 1(11).

Maysami, R. C. and V. P. Goby 1998a. 'The Impact of Cultural Trends on Business Practices'. Journal of Enterprising Culture 6(3): 333-346.

Maysami, R. C., V. P. Goby, and Y. W. Sok 1998b. 'Ethnicity and Entrepreneurship: Comments on Singaporean Chinese'. Asian Entrepreneur 7(1\&2): 11-18.

Maysami, R. C. and V. P. Goby 1999. 'Female Small Business Owners in Singapore and Elsewhere: A Review of Recent Studies'. Journal of Small Business Management 37(2): 96-105.

McClelland, D. 1961: The Achieving Society. Princeton: D. Van Nostrand.

McGraw, T. K. 1991. Schumpeter Ascending (Re-emerging Intellectual Interest in Entrepreneurship, Innovation and Economic Development). The American Scholar: 371-392.

Mill, J. S. 1984. Principles of Political Economy with Some Applications to Social Philosophy. London: John W. Parker.

MTI - Economic Vision - KBE Challenges \& Implications 2000. Available from: http:/ / www.mti.gov.sg/public/econovision/body4.cfm 
National University of Singapore Muslim Society and National University of Singapore Malay Society 1982. 'Transformasi Nilai dan Pembangunan dalam Masyarakat Melayu'. Paper for Mendaki Congress 1982.

$\mathrm{Ng}$, B.K. and E. J. Ng 1994. 'Dynamism of Small Chinese Business Enterprises in Malaysia and Singapore'. Journal of Enterprising Culture 1(3 \& 4):. 497-508.

Noordin, S. 1996. 'The Mat Rokers'. In S. Kishnan (ed) Looking at Culture. Singapore: Artres Design \& Communications 1996: 34-40.

Perry, C. 1990. 'After Further Sightings of the Heffalump'. Journal of Managerial Psychology 5(2): 22-31.

Pye, L.W. 1972. China: An Introduction. Boston: Little Brown.

Rahim-Ata-ur, A. 1979. Jesus a Prophet of Islam. London: MWH Publishers.

Redding, S. 1986. 'Entrepreneurship in Asia'. Euro-Asia Business Review. 5(4): 23-27.

Robinson, P. B., D. V., Stimpson, J.C., Huefner and H.K., Hunt 1990. 'An Attitude Approach to the Prediction of Entrepreneurship'. Entrepreneurship: Theory and Practice 15(1-4).

Rosenstien, C. and I. Light 1995. Race, Ethnicity, and Entrepreneurship in Urban America. Edison, NJ: Transaction Publishers.

Rotter, J. B. 1966. 'Generalized Expectancies for Internal Versus External Locus of Control of Reinforcement'. Psychological Monographs: General and Applied 80(Serial No. 609): 1 - 28.

Schumpeter, J. A. 1971. 'The Fundamental Phenomenon of Economic Development'. In P. Kilby (ed) Entrepreneurship and Economic Development. New York: The Free Press 1971: 43-70.

Schumpeter, J. A. 1954. History of Economic Analysis $6^{\text {th }}$ edition (Elizabeth Boody Schumpeter, ed). New York: Oxford University Press, and/or London: George Allen and Unwin 1967.

Setty, E.D. 1980. Developing Entrepreneurship: Issues and Problems. Hyderabad: Small Industry Training Institute.

Sexton, D. L. and N. Bowman 1985. 'The Entrepreneur: A Capable Executive and More'. Journal of Business Venturing 1.

Shapero, A. 1984. 'The Entrepreneurial Event'. The Environment for Entrepreneurship. Lexington, MA: D.C. Health 1954:.21-40.

Shaver, K.G. and L.R. Scott 1991. 'Person, Process, Choice: The Psychology of New Venture Creation'. Entrepreneurship: Theory and Practice 16(Winter): 23 - 45.

Singapore Population Census 2000, Department of Statistics. Available from: http:/ / www.singstat.gov.sg/

Singh, S.P., R.G Reynolds and S. Muhammad (2001). 'A Gender-Based Performance Analysis of Micro and Small Enterprises in Java'. Indonesia Journal of Small Business Management 39(2): 174-182.

Srinivasan, R. 1990. Cultures of the World: India. Singapore: Times Books International.

Stern, R.W. 1993. Changing India. Cambridge: Cambridge University Press.

Stevenson, H. H., M. J. Roberts and H. I. Grousbeck 1989. New Business Ventures and the Entrepreneur. Homewood, IL: Irwin.

Sumathi, S.T. 1994. 'Aspects of Indian Culture'. The Contributions of the Tamils to Indian Culture Vol. 3: Socio-Cultural Aspects. Madras: International Institute of Tamil Studies, CIT Campus, Tharamani 1994: 199-219.

Tamney, J.B. 1996. The Struggle over Singapore's Soul: Western Modernization and Asian Culture. Berlin, New York: Walter de Gruyter.

Teo S.K. 1996. 'Women Entrepreneurs of Singapore'. Singapore Business Development 
Ramin Cooper Maysami and Christopher Ziemnowicz

Series: Entrepreneurs, Entrepreneurship and Enterprising Culture: 254-289.

Terpstra, V. and D. Kenneth 1991. The Cultural Environment of International Business, Third Edition. Cincinnati, Ohio: South Western.

Tham, S. C. 1996. 'Cultural Forces and Counter Forces in Contemporary Singapore'. In E. Thumboo (ed) Cultures in ASEAN and the 21st Century. Singapore: UniPress, Centre for the Arts, National University of Singapore for ASEAN-COCI.

Thomas, A. S. and S. L Mueller 2000. 'A Case for Comparative Entrepreneurship: Assessing the Relevance of Culture'. Journal of International Business Studies 31(2): 287-301.

Timmons, J. A., L. E Smollen, and A. L. M. Dingee 1977. New Venture Creation, Homewood. Ill: Irwin.

Tong, C. K. and A. Pakir 1996. 'The Making of National Culture in Singapore'. In E. Thumboo (ed). Cultures in ASEAN and the 21st Century. Singapore: UniPress, Centre for the Arts, National University of Singapore for ASEAN-COCI.

Wee, V. 1976. 'Buddhism in Singapore'. In R. Hassan (ed) Singapore: Society in Transition. Kuala Lumpur: Oxford University Press 1976: 155-188.

Weiss, W. J. 1988. Regional Culture, Managerial Behavior, and Entrepreneurship: An International Perspective. New York: Quarom Book.

Wolpert, S. 1991. India. California: University of California Press.

Wong, S. K., L. K. Wong, Y.K. Kwan and V. C. Gansham 1993. A Conceptual Model for Depicting the Relationship Between Entrepreneurship and the Environmental Factors in Singapore. Paper presented at ' $4{ }^{\text {th }}$ ENDEC World Conference on Entrepreneurship: Dynamic Entrepreneurship', 1993.

Wu, Y.L. 1983. 'Chinese Entrepreneurs in Southeast Asia'. American Economic Review 73(2): 112-117.

Yeo, A. 1985. Living with Stress. Singapore: Times Books International. 